\title{
Comparative Effectiveness of a One-Year Follow-Up of Thoracic Medial Branch Blocks in Management of Chronic Thoracic Pain: A Randomized, Double-Blind Active Controlled Trial
}

Laxmaiah Manchikanti, MD'1 Vijay Singh, MD². Frank J.E. Falco, MD³. Kimberly A. Cash, RT ${ }^{1}$

Vidyasagar Pampati, $\mathrm{MSc}^{1}$, and Bert Fellows, $\mathrm{MA}^{1}$

From: ${ }^{1}$ Pain Management Center of Paducah, Paducah, KY; ${ }^{2}$ Pain Diagnostics Associates, Niagara, WI.

${ }^{3}$ Mid Atlantic Spine, Newark, NJ.

Dr. Manchikanti is Medical Director of the Pain Management Center of Paducah, Paducah, KY and Associate Clinical Professor, Anesthesiology and

Perioperative Medicine, University of Louisville, Louisville, KY.

Dr. Singh is Medical Director, Pain Diagnostics Associates, Niagara, WI.

Dr. Falco is Medical Director of the Mid Atlantic Spine \& Pain Physicians of Newark, DE; Director,

Pain Medicine Fellowship, Temple University Hospital, Philadelphia, PA and Associate Professor, Department of PM\&R, Temple University Medical School, Philadelphia, PA.

Kimberly A. Cash is a Research Coordinator at the Pain Management

Center of Paducah, Paducah, KY. Vidyasagar Pampati is a statistician at the Pain Management Center of Paducah, Paducah, KY. Bert Fellows is Director Emeritus of Psychological Services at the Pain Management Center of Paducah, Paducah, KY.

Address correspondence: Laxmaiah Manchikanti, MD 2831 Lone Oak Road

Paducah, Kentucky 42003

E-mail:drlm@thepainmd.com

Disclaimer: There was no external funding in the preparation of this manuscript.

Conflict of interest: None.

Manuscript received: 10/28/2010 Accepted for publication: 11/02/2010

Free full manuscript: www.painphysicianjournal.com
Background: Thoracic facet joints have been implicated as the source of chronic pain in the mid back or upper back in $34 \%$ to $42 \%$ of patients when the modified criteria of the International Association for the Study of Pain (IASP) is utilized. Various therapeutic techniques utilized in managing chronic thoracic pain of facet joint origin include intraarticular injections, medial branch blocks, and radiofrequency neurotomy of thoracic medial branch nerves.

Study Design: A randomized, double-blind, active controlled trial.

Setting: A private practice, interventional pain management setting, and a specialty referral center setting in the United States.

Objective: To determine the clinical effectiveness of therapeutic local anesthetic medial branch blocks with or without steroid in managing chronic function-limiting mid back or upper back pain of facet joint origin.

Methods: The study was performed in an interventional pain management private practice, a tertiary referral center, in the United States. A total of 100 participants were included, with 50 participants in each of the local anesthetic and steroid groups. All of the participants met the diagnostic criteria of thoracic facet joint pain by means of comparative, controlled diagnostic blocks and the inclusion criteria. Group I participants received thoracic medial branch blocks with bupivacaine, whereas Group II participants received thoracic medial branch blocks with bupivacaine and non-particulate betamethasone.

Outcomes Assessment: Outcomes measures included numeric rating scores (NRS), Oswestry Disability Index (ODI), opioid intake, and return to work status at baseline, 3 months, 6 months, and 12 months. Significant pain relief was defined as $\geq 50 \%$ pain relief and/or a positive change in ODI scores.

Results: In Group I and Group II 90\% of participants showed significant pain relief and functional improvement at 12 months.

The majority of the participants experienced significant pain relief of $47.2 \pm 10.1$ weeks in Group I and $46.3 \pm 8.4$ weeks in Group II, requiring approximately 3.5 treatments per year with an average relief of $15.8 \pm 10.5$ in Group I and $13.6 \pm 3.6$ weeks in Group II per episode of treatment.

Limitations: Study limitations include the lack of a placebo group.

Conclusions: Therapeutic thoracic medial branch blocks, with or without steroid, may provide a management option for chronic function-limiting mid back or upper back pain of facet joint origin.

Clinical Trial: NCT00355706

Key words: Chronic spinal pain, thoracic pain, thoracic facet or zygapophysial joint pain, facet joint nerve or medial branch blocks, comparative controlled local anesthetic blocks, therapeutic thoracic medial branch blocks.

Pain Physician 2010; 13:535-548 


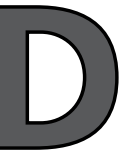

espite the relatively low proportion of mid back and upper back pain secondary to thoracic disorders, thoracic pain in interventional pain management settings ranges from $3 \%$ to $22 \%$ compared to the lifetime prevalence of spinal pain of $54 \%$ to $80 \%(1-3)$. The prevalence of thoracic pain has been estimated as $15 \%$ of the general population in contrast to $56 \%$ reporting low back pain and $44 \%$ reporting neck pain $(1,4)$. Even though involvement of thoracic facet joints as a cause of chronic mid back and upper back pain was described in 1987 (5), thoracic facet joint pain patterns were not described until 1994 (6) and 1997 (7).

In accordance with the modified criteria of the International Association for the Study of Pain (IASP) (8), utilizing $80 \%$ pain relief as the criterion standard and the ability to perform multiple prior painful movements with controlled, comparative, local anesthetic blocks, prevalence has been established as $34 \%$ to $42 \%$ (9-16), with an apparent false-positive rate ranging from $42 \%$ to $55 \%$ with a single block in a heterogenous population.

Atluri et al (12), evaluating the diagnostic value and therapeutic role of facet joint interventions, determined significant value for diagnostic medial branch blocks and established moderate evidence. However, for therapeutic interventions they were able to establish moderate evidence only for medial branch blocks, with no evidence for intraarticular injections or radiofrequency neurotomy.

Significant debate surrounds the appropriate management of thoracic facet joint pain for diagnostic as well as therapeutic interventions. Further, similar debate surrounds diagnostic and therapeutic medial branch blocks for lumbar and cervical facet joint diagnosis and therapy (15-32).

Confusion surrounding facet joint interventions is based on lack of understanding of placebo control and the criterion standard $(24,25,27)$. However, the criterion standard is not only limited to biopsy, but also longterm follow-up criteria $(33,34)$. Studies in the lumbar spine have shown the value of controlled comparative local anesthetic blocks with $80 \%$ concordant pain relief with long-term follow-up of 2 years (35-38). Further, the influence of multiple confounding factors has also been evaluated without influence on the diagnostic value of cervical and facet joint nerve blocks (39-46). Despite the ongoing debate it appears that diagnostic facet joint nerve blocks are the accurate method of diagnosis at the present time.
Similar to the diagnostic aspects, significant debate surrounds the appropriate management of facet joint pain $(22,23,37,38,47-52)$. The systematic review by Atluri et al (12) showed a lack of evidence for therapeutic thoracic intraarticular facet joint injections and radiofrequency neurotomy, whereas they showed moderate evidence for thoracic medial branch blocks, which has also been reported in other studies $(16,17)$. Previously, Manchikanti et al (49) published preliminary results of a randomized, double-blind trial showing positive results in $79 \%$ of the participants receiving local anesthetic blocks with or without steroids. The results of this trial were superior to an observational report (50).

This report consists of the one-year results of a continuation of the preliminary report (49) using a randomized, double-blind controlled trial in participants with a confirmed diagnosis of thoracic facet joint pain by means of comparative, controlled, local anesthetic blocks based on modified IASP criteria with $80 \%$ pain relief and the ability to perform previously painful movements $(8,12,15,16)$.

\section{Methods}

This evaluation was conducted in the United States on participants suffering with chronic, function-limiting, thoracic facet joint pain. The study site is an interventional pain management practice, a specialty referral center, in a private practice setting. The study was designed to meet clinical protocol criteria and Consolidated Standards of Reporting Trials (CONSORT) guidelines (53-55).

The study protocol was approved by the Institutional Review Board of the Ambulatory Surgery Center. The study was registered on the U.S. Clinical Trial Registry with an assigned number of NCT00355706.

\section{Participants}

All the participants were recruited at an interventional pain management practice from consecutive new patients presenting with thoracic pain without suspected disc herniation, radiculitis, thoracic fracture, stenosis, or intercostal neuritis. Eligible patients with a confirmed diagnosis of thoracic facet joint pain by controlled comparative local anesthetic blocks were assigned to one of 2 groups with Group I constituting a nonsteroid group, and Group II encompassing a steroid group. Group I participants received medial branch blocks with injections of bupivacaine $0.25 \%$, whereas Group II participants received medial branch blocks with a mixture of bupivacaine and non-par- 
ticulate betamethasone. Non-particulate betamethasone $(0.15 \mathrm{mg})$ was added to each $\mathrm{mL}$ of bupivacaine solution.

\section{Inclusion and Exclusion Criteria}

Only patients with non-specific mid back or upper back pain were included. Patients suspected of disc related pain with radicular symptoms were excluded based on radiologic testing and symptomatology involving radicular or chest wall pain. Only patients who had failed conservative management, including physical therapy, chiropractic manipulation, exercises, drug therapy, and bedrest were included.

Inclusion criteria were a diagnosis of thoracic facet joint pain by means of controlled comparative local anesthetic blocks; patients who were over 18 years of age; patients with a history of chronic function-limiting thoracic pain of at least 6 months duration; and patients who were competent to understand the study protocol and provide voluntary, written informed consent and participate in the outcome measurements.

Exclusion criteria were a lack of positive response to controlled comparative local anesthetic blocks, uncontrollable or heavy opioid use (morphine equivalence of $300 \mathrm{mg}$ or more), uncontrolled psychiatric disorders, uncontrolled medical illness either acute or chronic, any condition that could interfere with the interpretation of the outcome assessments such as positioning women who were pregnant or lactating, and patients with a history or potential for adverse reaction(s) to local anesthetic or steroid.

\section{Interventions}

\section{Diagnostic Facet Joint Nerve Blocks}

The diagnosis of facet joint pain was made by controlled comparative local anesthetic blocks in all patients, in accordance with modified IASP criteria (8-10). All thoracic facet joints were evaluated with controlled comparative facet joint nerve blocks with a diagnostic process starting with diagnostic facet joint nerve blocks using $0.5 \mathrm{~mL}$ of $1 \%$ preservative-free lidocaine, followed by $0.5 \mathrm{~mL}$ of $0.25 \%$ preservative-free bupivacaine on a separate occasion, usually 3-4 weeks after the first injection, if positive with lidocaine. Target joints were identified by the pain pattern, local or paramedian tenderness over the area of the facet joints, and reproduction of the pain with deep pressure. A positive response was considered when a patient reported at least an $80 \%$ reduction of pain assessed by a numeric rating scale (NRS) and the ability to perform previously painful movements with continued relief of at least $80 \%$. In addition, a positive response was only considered if the pain relief lasted at least 2 hours following the lidocaine injection and lasted at least 3 hours or greater than the duration of relief with lidocaine when bupivacaine was used; all other responses were considered as negative.

The facet joint nerve blocks were performed on the ipsilateral side in patients with unilateral pain, and bilateral facet joint nerve blocks were performed if patients had only axial pain or bilateral pain. Each nerve was injected with 0.5 of the local anesthetic and the blocks were performed on a minimum of 2 nerves to block a single joint and 3 nerves on 2 consecutive joints.

\section{Therapeutic Facet Joint Nerve Blocks}

Therapeutic facet joint nerve blocks were performed at the same levels as the diagnostic facet joint nerve blocks which led to the inclusion into the study utilizing solutions as assigned into Group I or Group II with or without steroids. All therapeutic facet joint nerve blocks were performed in a sterile setting in the operating room under fluoroscopy with a 22-gauge, 2" spinal needle with injection of a 0.5 to $1 \mathrm{~mL}$ mixture.

\section{Co-interventions}

New or specific co-interventions such as physical therapy, occupational therapy, or bracing were not offered during this treatment. However, the same cointerventions as scheduled including physical therapy and exercise program along with opioid and non-opioid analgesics, and adjuvant analgesics were continued in all participants as necessary.

\section{Additional Interventions}

Participants were followed at 3-month intervals unless otherwise indicated. Thoracic medial branch blocks were repeated based only on improvement in physical and functional status following prior intervention, with deterioration of pain level to below $50 \%$.

\section{Objective}

The objective of this randomized, double-blind, active controlled trial was to determine the clinical outcomes of therapeutic thoracic medial branch blocks with local anesthetic with or without steroids in managing chronic thoracic pain of facet joint origin. 


\section{Outcomes}

Outcomes measured included NRS, Oswestry Disability Index (ODI), work status, and opioid intake in terms of morphine equivalents, assessed at baseline, 3 , 6 , and 12 months post-treatment.

Significant improvement was defined as at least $50 \%$ pain relief and/or improvement in ODI. NRS represented " 0 " with no pain and "10" with worst pain imaginable. The NRS has been frequently utilized for pain measurements and its value and validity have been reported (54-56). The ODI has been shown to be valid and reliable in patients with mechanical low back pain measured on a scale of 0 to 50 with " 0 " being no disability and " 50 " being the worst disability $(54,55,57-61)$. Further, reported thresholds for the minimum clinically important difference for the ODI ranged from a $2 \%$ to $40 \%$ change, even though recent literature demands higher improvements for outcome measurements (54,55,57-63).

Opioid intake was evaluated based on the dosage frequency and schedule of the drug, with conversion to morphine equivalents (64).

Participants unemployed or employed on a parttime basis with limited or no employment due to pain were classified as employable. Participants who chose not to work, were retired, or were homemakers (not working, but not due to pain) were not considered in the employment pool.

\section{Sample Size}

For this evaluation, a sample size of 50 patients for each group was chosen. The sample size was much smaller in previous studies of cervical (65) and lumbar (66) medial branch neurotomies, which included less than 20 participants in each group. The literature evaluating the quality of individual studies has shown a sample size of 50 patients in the smallest group as acceptable (67).

\section{Randomization/Sequence Generation}

A total of 100 participants were randomized with 50 participants into each group. Computer generated random allocations sequence concealment was utilized.

\section{Allocation Concealment}

Participants were randomized and the drugs were prepared appropriately by the operating room nurse assisting with the procedure. All mixtures consisted of clear solutions of bupivacaine or bupivacaine and nonparticulate betamethasone.

\section{Implementation}

After the participants met the inclusion criteria, one of the 3 nurses assigned as coordinators of the study enrolled and assigned them to their respective groups. All the participants meeting inclusion criteria were invited to enroll in the study.

\section{Blinding}

The random allocation was not revealed to personnel in the recovery room or to the physician performing the procedure. Study participants were mixed with other patients with no specific indication that they were participating in the study.

Participants were unblinded if they requested to be unblinded or after completing 24 months of the study. Participants were provided with an opportunity to discontinue or withdraw from the study for lack of pain relief or for any other reason. All the participants with loss of follow-up or premature unblinding were considered to be withdrawn.

All the participants will be unblinded at 24 months.

\section{Statistical Methods}

Chi-squared statistic, Fisher's exact test, paired ttest, and one-way analysis of variance were used to analyze the data.

Chi-squared statistic was used to test the differences in proportions. Fisher's exact test was used wherever the expected value was less than 5 . A paired t-test was used to compare the pre- and post-treatment results of average pain scores and the ODI measurements at baseline versus 3,6 , and 12 months. The t-test was performed for comparison of mean scores between groups. One-way analysis of variance was used for comparison of means among groups.

\section{Intent-to-Treat-Analysis}

An intent-to-treat-analysis was utilized on all participants utilizing the last follow-up data. Initial data were utilized for the participants who dropped out of the study without further follow-up after first treatment. Sensitivity analysis was performed utilizing best case, worst case, average value, and last follow-up scores scenarios.

\section{Results}

\section{Participant Flow}

Figure 1 illustrates the participant flow. 


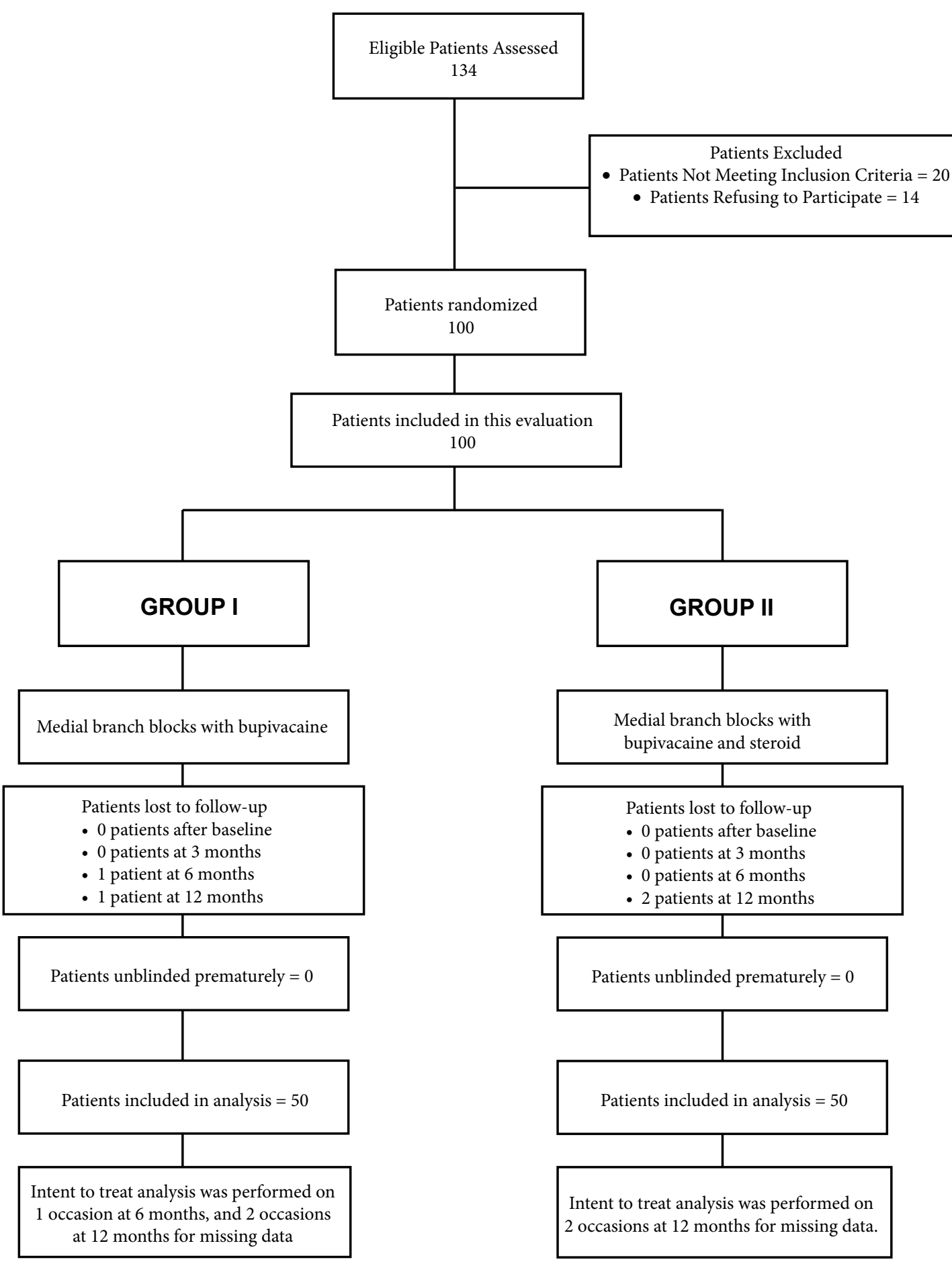

Fig. 1. Schematic presentation of participant flow at one-year follow-up. 


\section{Recruitment}

The recruitment period started in 2003 and lasted through August 2009.

\section{Baseline Data}

Demographic characteristics are illustrated in Table 1.

The number of joints was as follows: 2 joints were involved in $22 \%$ of the participants, 3 joints were involved in $31 \%$ of the participants and 4 joints were involved in $47 \%$ of the participants. Bilateral involvement was seen in $67 \%$ of the participants.

\section{Analysis of Data}

\section{Numbers Analyzed}

As illustrated in Fig. 1, all 100 participants were utilized in the analysis.

\section{Outcomes}

\section{Pain Relief}

Numeric pain scale scores are illustrated in Table 2 and Fig. 2. The percentage of participants with significant pain relief was $90 \%$ at one-year follow-up in both groups.

Table 3 illustrates therapeutic procedural characteristics with average pain relief over a period of oneyear. Average relief per procedure was $15.8 \pm 10.5$ and $13.6 \pm 3.6$ weeks per procedure, whereas it was $47.2 \pm$ 10.1 and $46.3 \pm 8.4$ weeks over a period of one-year respectively for total pain relief.

\section{Functional Assessment}

Table 4 illustrates functional assessment characteristics evaluated by ODI. At least $50 \%$ improvement was seen in $80 \%$ and $84 \%$, at one-year in Groups I and II respectively.

Table 1. Demographic characteristics.

\begin{tabular}{|c|c|c|c|c|}
\hline & & $\begin{array}{l}\text { Group I } \\
(\mathrm{N}=50)\end{array}$ & $\begin{array}{c}\text { Group II } \\
(\mathbf{N}=\mathbf{5 0})\end{array}$ & $P$ value \\
\hline \multirow{2}{*}{ Gender } & Male & $38 \%(19)$ & $36 \%(18)$ & \multirow{2}{*}{0.836} \\
\hline & Female & $62 \%(31)$ & $64 \%(32)$ & \\
\hline Age & Mean \pm SD & $44.7 \pm 11.7$ & $42.8 \pm 12.3$ & 0.431 \\
\hline Height (inches) & Mean \pm SD & $67.5 \pm 3.9$ & $65.9 \pm 3.9$ & 0.042 \\
\hline Weight (lbs.) & Mean \pm SD & $197.6 \pm 53.2$ & $172.3 \pm 37.1$ & 0.007 \\
\hline BMI & & $30.2 \pm 6.6$ & $28.0 \pm 3.3$ & 0.079 \\
\hline Duration of pain (months) & Mean \pm SD & $78.0 \pm 68.8$ & $77.0 \pm 73.6$ & 0.994 \\
\hline \multirow{2}{*}{ Mode of onset of Pain } & Non-Traumatic & $68 \%(34)$ & $72 \%(36)$ & \multirow{2}{*}{0.663} \\
\hline & Traumatic & $32 \%(16)$ & $28 \%(14)$ & \\
\hline \multicolumn{2}{|c|}{ History of previous thoracic surgery } & $2 \%(1)$ & $6 \%(3)$ & 0.617 \\
\hline
\end{tabular}

Group I = bupivacaine only

Group II = bupivacaine and steroid

Table 2. Pain relief characteristics

\begin{tabular}{||c|c|c|c|c||}
\hline & & $\begin{array}{c}\text { Group I } \\
\text { (N=50) }\end{array}$ & $\begin{array}{c}\text { Group II } \\
\text { (N=50) }\end{array}$ & P value \\
\hline $\begin{array}{l}\text { Average Pain Scores } \\
\text { (Mean } \pm \text { SD) }\end{array}$ & Baseline & $7.9 \pm 0.93$ & $7.8 \pm 1.0$ & 0.840 \\
\cline { 2 - 5 } & 3 months & $3.1^{*} \pm 0.9$ & $3.1^{*} \pm 0.7$ & 1.000 \\
\cline { 2 - 5 } & 6 months & $3.0^{*} \pm 0.9$ & $3.2^{*} \pm 0.8$ & 0.481 \\
\cline { 2 - 5 } & 12 months & $3.2^{*} \pm 0.9$ & $3.1^{*} \pm 1.0$ & 0.833 \\
\hline
\end{tabular}

${ }^{*}$ indicates significant difference with baseline values $(P<0 / 05)$

Group I = bupivacaine only

Group II = bupivacaine and steroid 


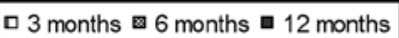

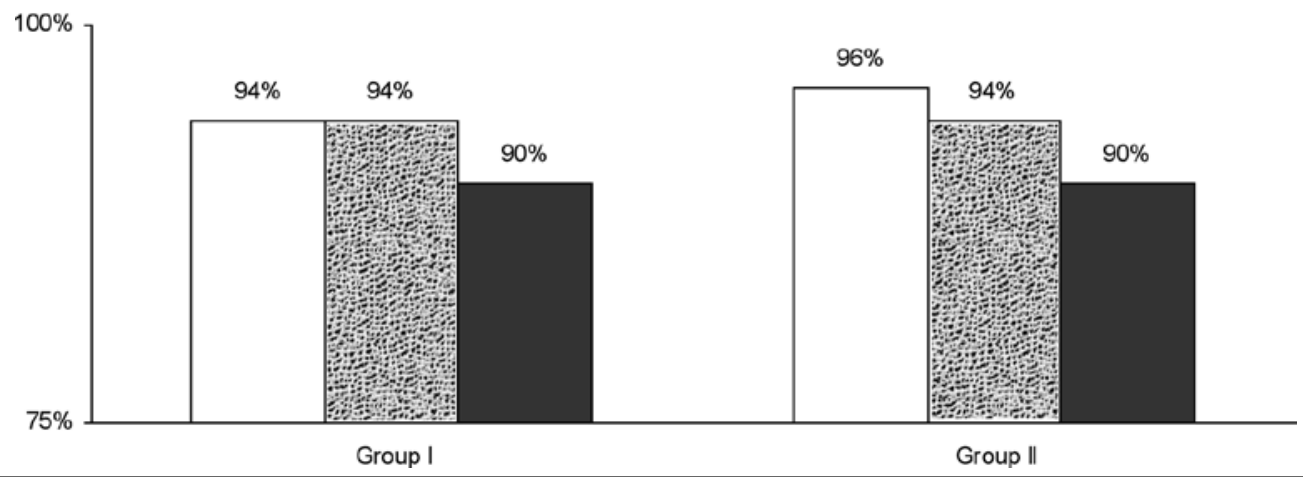

Fig. 2. Illustration of significant pain relief ( $\geq 50 \%)$.

Table 3. Therapeutic procedural characteristics with procedural frequency, average relief per procedure, and average total relief in weeks over a period of 1-year.

\begin{tabular}{|c|c|c|c|c|}
\hline \multirow[b]{2}{*}{$\begin{array}{l}\text { Number of } \\
\text { Procedures }\end{array}$} & \multicolumn{2}{|c|}{$\begin{array}{l}\text { Group I } \\
(\mathrm{N}=\mathbf{5 0})\end{array}$} & \multicolumn{2}{|c|}{$\begin{array}{c}\text { Group II } \\
(\mathbf{N}=\mathbf{5 0})\end{array}$} \\
\hline & $\begin{array}{l}\text { Average relief } \\
\text { Per procedure }\end{array}$ & $\begin{array}{c}\text { Average } \\
\text { Total relief }\end{array}$ & $\begin{array}{l}\text { Average relief } \\
\text { Per procedure }\end{array}$ & $\begin{array}{c}\text { Average } \\
\text { Total relief }\end{array}$ \\
\hline One & $\begin{array}{l}52 \\
(3) \\
\end{array}$ & $\begin{array}{l}52 \\
(3) \\
\end{array}$ & $\begin{array}{c}22.7 \pm 5.8 \\
(3) \\
\end{array}$ & $\begin{array}{c}22.7 \pm 5.8 \\
(3)\end{array}$ \\
\hline Range & 52 & 52 & $16-26$ & $16-26$ \\
\hline Two & $\begin{array}{c}19.3 \pm 11.4 \\
(7)\end{array}$ & $\begin{array}{c}38.6 \pm 22.9 \\
(7)\end{array}$ & $\begin{array}{c}19.5 \pm 6.5 \\
\text { (3) }\end{array}$ & $\begin{array}{c}39.0 \pm 13.0 \\
\text { (3) }\end{array}$ \\
\hline Range & $4-52$ & $2-52$ & $13-52$ & $26-52$ \\
\hline Three & $\begin{array}{c}14.8 \pm 2.4 \\
(8)\end{array}$ & $\begin{array}{l}44.4 \pm 7.1 \\
\quad(8)\end{array}$ & $\begin{array}{c}14.9 \pm 2.2 \\
(9)\end{array}$ & $\begin{array}{l}44.7 \pm 6.8 \\
(9)\end{array}$ \\
\hline Range & $3-52$ & $36-52$ & $13-52$ & $35-52$ \\
\hline Four & $\begin{array}{c}12.3 \pm 1.2 \\
(32)\end{array}$ & $\begin{array}{c}49.1 \pm 4.8 \\
(32)\end{array}$ & $\begin{array}{c}12.4 \pm 1.0 \\
(35)\end{array}$ & $\begin{array}{c}49.4 \pm 3.9 \\
(35)\end{array}$ \\
\hline Range & $0-20$ & $37-52$ & $0-30$ & $38-52$ \\
\hline Five & & & - & \\
\hline Range & $9-14$ & $47-52$ & & \\
\hline $\begin{array}{l}\text { Average/Total } \\
\text { Per } 1 \text { year }\end{array}$ & $\begin{array}{c}15.8 \pm 10.5 \\
(50)\end{array}$ & $\begin{array}{l}47.2 \pm 10.1 \\
\quad(50)\end{array}$ & $\begin{array}{c}13.6 \pm 3.6 \\
(50)\end{array}$ & $\begin{array}{l}46.3 \pm 8.4 \\
\quad(50)\end{array}$ \\
\hline Range & $2-52$ & $4-52$ & $10-26$ & $16-52$ \\
\hline
\end{tabular}

Table 4. Functional assessment evaluated by Oswestry Disability Index.

\begin{tabular}{|l|l|c|c|c||}
\hline & & $\begin{array}{c}\text { Group I } \\
\text { (N=50) }\end{array}$ & $\begin{array}{c}\text { Group II } \\
\text { (N=50) }\end{array}$ & P value \\
\hline \multirow{2}{*}{$\begin{array}{l}\text { Disability Scores } \\
\text { (Mean } \pm \text { SD) }\end{array}$} & Baseline & $27.1 \pm 6.6$ & $27.5 \pm 5.8$ & 0.708 \\
\cline { 2 - 6 } & 3 months & $13.0^{*} \pm 4.9$ & $11.6^{*} \pm 3.7$ & 0.122 \\
\cline { 2 - 6 } & 6 months & $13.0^{*} \pm 4.2$ & $11.9^{*} \pm 3.8$ & 0.636 \\
\cline { 2 - 6 } & 12 months & $12.0^{*} \pm 4.0$ & $11.8^{*} \pm 3.9$ & 0.780 \\
\hline
\end{tabular}

${ }^{*}$ indicates significant difference with baseline

Group I = bupivacaine only

Group II = bupivacaine and steroid 


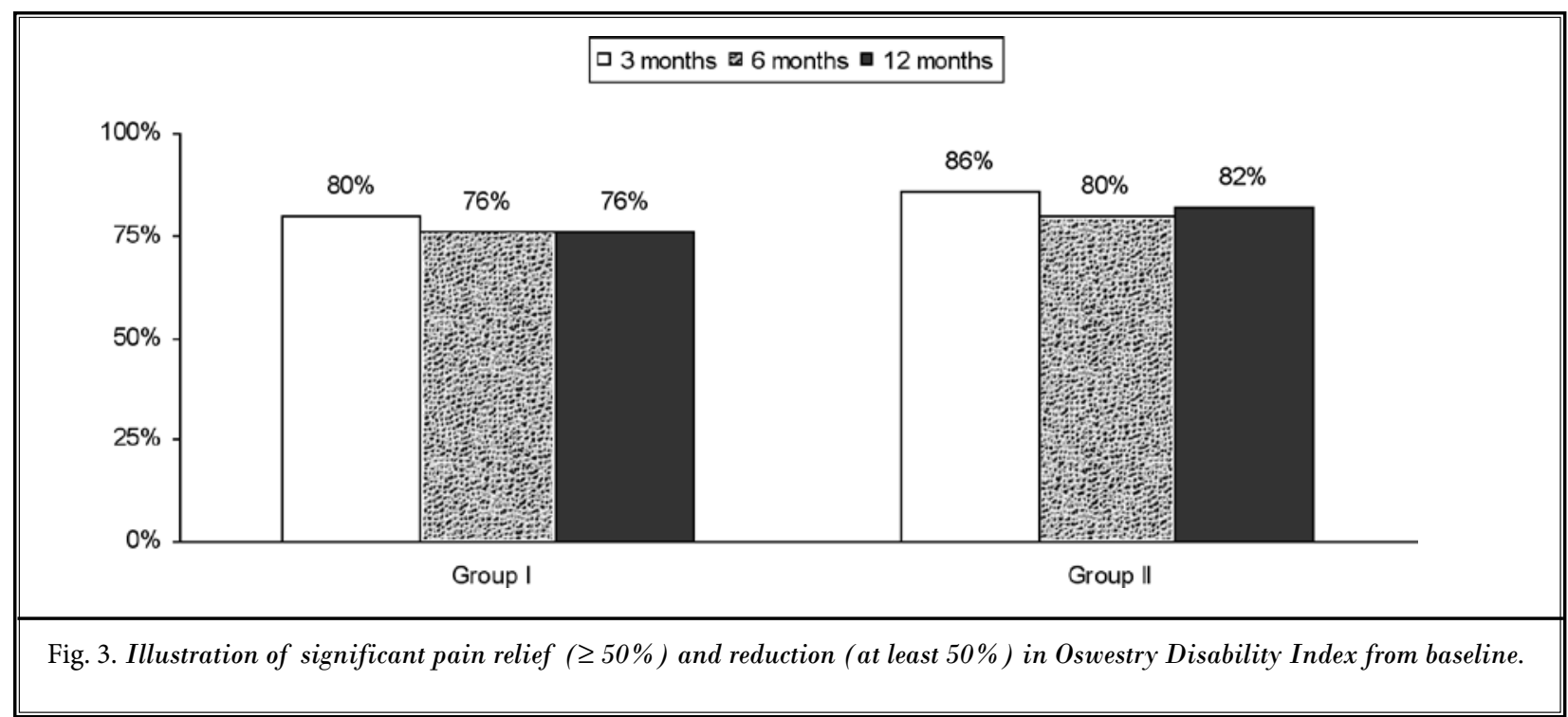

Table 5. Opioid intake (morphine equivalence mg).

\begin{tabular}{|c|c|c|c|}
\hline \multirow{2}{*}{$\begin{array}{c}\text { Narcotic intake } \\
\text { (Morphine Equivalence mg) }\end{array}$} & Group I (60) & Group II (60) & \multirow{2}{*}{$P$ value } \\
\hline & Mean \pm SD & Mean \pm SD & \\
\hline Baseline & $48.0 \pm 53.75$ & $47.9 \pm 48.6$ & 0.992 \\
\hline 3 months & $38.0 \pm 44.2$ & $40.3 \pm 33.9$ & 0.769 \\
\hline 6 months & $38.2 \pm 46.1$ & $39.3 \pm 34.8$ & 0.889 \\
\hline 12 months & $37.6 \pm 38.4$ & $37.8 \pm 33.2$ & 0.976 \\
\hline
\end{tabular}

\section{Pain and Functional Status Improvement}

Figure 3 illustrates the proportion of patients with significant pain relief $(>50 \%)$ in combination with reduction of at least $50 \%$ in the disability scores from baseline, which was seen in $76 \%$ of the patients in Group I and $82 \%$ in Group II at 12 months.

\section{Opioid Intake}

Table 5 illustrates opioid intake with no significant change in intake of opioids.

\section{Employment Characteristics}

Table 6 illustrates the summary of employment characteristics in both groups.

\section{Adverse Events}

No major adverse events were reported during this study including infection, pneumothorax, nerve root trauma, or spinal cord trauma.

\section{Discussion}

This randomized, double-blind trial, of 100 patients undergoing therapeutic thoracic medial branch nerve blocks who had chronic, function-limiting mid back or upper back pain secondary to thoracic facet joint involvement showed significant improvement with decreased pain and improved functional status. Significant pain relief of $50 \%$ or greater of varying duration was seen in $90 \%$ of participants in both groups. Functional assessment measured by ODI also showed significant improvement with at least a $50 \%$ reduction of disability scores in $80 \%$ of participants in Group I and $84 \%$ of participants in Group II over a period of one-year. Combined $\geq 50 \%$ pain relief and $\geq$ $50 \%$ improvement in ODI scores was seen in $76 \%$ and $82 \%$ of participants in Group I and II respectively at 12 months. The average pain relief per procedure ranged from 14 to 16 weeks and participants experienced 46 to 47 weeks of significant pain relief during one-year. 
Table 6. Employment characteristics.

\begin{tabular}{|l|c|c|c|c||}
\hline \multirow{2}{*}{ Employment status } & \multicolumn{2}{c|}{ Group I } & \multicolumn{2}{c|}{ Group II } \\
\cline { 2 - 5 } & Baseline & $\mathbf{1 2}$ months & Baseline & 12 \\
\hline Employed part-time & 5 & 5 & 14 & 3 \\
\hline Employed full-time & 10 & 14 & 3 & 16 \\
\hline Unemployed & 3 & 1 & 0 & 0 \\
\hline Unemployed - Student & 1 & 0 & 15 & 19 \\
\hline Total Employed & 15 & 19 & 3 & 18 \\
\hline Eligible for employment & 19 & 19 & 27 & 2 \\
\hline Housewife & 2 & 1 & 2 & 25 \\
\hline Disabled & 23 & 23 & 50 & 3 \\
\hline Over 65 years of age & 6 & 6 & 50 \\
\hline Total number of participants & 50 & 50 & & 5 \\
\hline
\end{tabular}

However, there were no differences in opioid use or employment.

This randomized trial was designed to reflect everyday clinical practice as others have also done $(38,53)$. The results showed that the combination of steroid with local anesthetic failed to provide additional improvement. There were no significant differences of any clinical importance in any of the parameters. This is one of the largest studies with the longest follow-up of an interventional technique, specifically in managing thoracic facet joint pain. This study, similar to other studies, evidently resolves the issue of adding steroids to local anesthetic in therapeutic medial branch blocks. The evidence shows that there is no significant role for steroids in thoracic medial branch blocks.

The basis for intraarticular injections has been that if there is inflammation, steroids are used to treat the inflammation. Further, the literature is replete with descriptions of epidural corticosteroids providing a certain level of efficacy by their anti-inflammatory, immuno-suppressive, anti-edema effects, and inhibition of neurotransmission within the C-fibers (68-71). At the same time, local anesthetics also have been described to provide long-term symptomatic relief, even though the mechanism of this relief continues to be an enigma and widely debated $(37,38,52,53,72-82)$. However, multiple postulations have lead to the impressions that local anesthetics provide relief by suppression of nociceptive discharge (72), the blockade of the axonal transport $(83,84)$, the blockade of sympathic reflex arc, the blockade of sensitization $(85,86)$, and by exerting anti-inflammatory effects (87).
The limitations of this study include a lack of placebo control. As it is not well known to some, placebo control in any neural blockade is an extremely difficult task. In addition, placebo control is complicated with ethical issues and difficulty with recruitment in the United States. Further, multiple investigators performing placebo-controlled studies in interventional pain management have incorporated substantial design flaws $(22,23,47,48,54,55$ ,88,89). Many researchers ignore the fact that any solution injected into a closed space such as the intraarticular space or epidural space or over a nerve root, whether it is placebo or an active agent, has not been well studied and we are not aware of the effects of placebo solutions. Carette et al $(90,91)$ in widely acclaimed studies, showed that patients responded similarly to an intraarticular injection or epidural injection whether it contained a sodium chloride solution or local anesthetic with steroid, with low response in all the groups. However, the results have been misinterpreted by some. They concluded that since sodium chloride solution injected into an intraarticular space or epidural space has similar results to local anesthetic with steroid, then intraarticular steroids or epidural steroids are not only an effective therapy and that any local anesthetic injection provides only placebo effect. Further, in the recent literature, the issue has been exemplified by Birkenmaier et al (92), who described the utilization of either pericapsular injections or medial branch blocks before performing cryoneurolysis. Not surprisingly, the results were superior in patients who were diagnosed using medial branch blocks rather than pericapsular injections of local anesthetic. This study was the basis for Chou and Huffman (88) to discard the value of diagnostic lumbar facet joint nerve blocks. 
In addition, the literature shows differing effects with injections of various solutions such as local anesthetic, normal saline, or dextrose, and also shows differing effects by injection into the disc, facet joint, or multifidus muscle (28-31,93-95). It was also demonstrated that a small volume of local anesthetic or normal saline abolishes muscle twitching caused by a low current $(0.5 \mathrm{~mA})$ during electrode location $(28,29,93)$. Further, complicating the understanding of placebo analgesia, there is also direct evidence for spinal cord involvement (94). In addition, it has been reported that epidurally administered sodium chloride solution provides significant improvement in pain and function $(29,95)$. Thus, the evidence here in this manuscript leads to the conclusion that the effect of local anesthetic on thoracic medial branch blocks cannot be attributed to placebo effect, even though some have mistakenly misinterpreted this to be the case for facet joint nerve blocks $(25,27,96)$. Placebo effects are not expected to be seen in a high proportion of patients, nor are they expected to be long-lasting with repeat interventions over a period of 1-2 years. Even then, the limitations of lack of placebo must not be underestimated. If feasible, a placebo-controlled study with appropriate design that includes not injecting the placebo solution over the medial branches, and subsequent results, would be highly valid and provide conclusive knowledge on the issue of placebo-controlled blocks.

The second issue is related to the reliability of the controlled, comparative local anesthetic blocks, which have been criticized and their validity as precision diagnostic techniques has been questioned and debated (8-16,19-22). The issues related to the accuracy of diagnostic facet joint nerve blocks include the reference standard, prior exposure to opioids, sedation, systemic local anesthetic, and non-specific effect resulting in positive results have been essentially resolved $(8-16,19-$ 22, 35-38,51,52,97).

The results of this trial illustrate the practice patterns from a real world setting, specifically private practice settings in the United States specializing in the practice of interventional pain management. Consequently, the results may be generalizable to similar settings. In the modern arena of comparative effectiveness research and evidence-based medicine, the practical clinical trials (98) measuring effectiveness are considered more appropriate than explanatory trials measuring efficacy (99). Considering that practical trials are best designed to provide results of the benefit of treatments produced in routine clinical practice and also to address questions about the risks, benefits, and costs of intervention as they occur in routine, clinical practice better than explanatory trials, the design of this study and the results of this study are not only appropriate, but also are applicable. However, the results of this study are not applicable in the general population unless the same methodology is utilized with diagnosis and therapy. Further, the generalizability of the findings of this study may only be feasible with the publication of studies utilizing larger populations in multiple settings.

\section{Conclusions}

The evidence in this report demonstrates that thoracic facet joint pain diagnosed by controlled, comparative local anesthetic blocks with criteria of $80 \%$ pain relief, which is sustained even during previously painful movements for an appropriate duration of action of the local anesthetic, may be treated with therapeutic thoracic medial branch blocks with or without steroid.

\section{Acknowledgments}

The authors wish to thank Sekar Edem for assistance in the search of the literature, Tom Prigge for manuscript review, and Tonie M. Hatton and Diane E. Neihoff, transcriptionists, for their assistance in preparation of this manuscript. We would like to thank the editorial board of Pain Physician for review and criticism in improving the manuscript.

\section{References}

1. Manchikanti L. Singh V, Datta S, Cohen SP, Hirsch JA. Comprehensive review of epidemiology, scope, and impact of spinal pain. Pain Physician 2009; 12:E35-E70.

2. Manchikanti L, Pampati VS. Research designs in interventional pain management: Is randomization superior, desirable or essential? Pain Physician 2002; 5:275-284.
3. Stolker RJ, Vervest AC, Groen GJ. Percutaneous facet denervation in chronic thoracic spinal pain. Acta Neurochir 6 . 1993; 122:82-90.

4. Linton SJ, Hellsing AL, Hallden K. A population based study of spinal pain among 35-45-year-old individuals. Spine (Phila Pa 1976) 1998; 23:1457- 7. 1463.

5. Wilson PR. Thoracic facet joint syn- drome - a clinical entity? Pain Suppl 1987; 4:S87.

Dreyfuss P, Tibiletti C, Dreyer SJ. Thoracic zygapophyseal joint pain patterns: A study in normal volunteers. Spine (Phila Pa 1976) 1994; 19:807811.

Fukui S, Ohseto K, Shiotani M. Patterns of pain induced by distending the thoracic zygapophyseal joints. Reg Anesth 1997; 22:332-336. 
8. Merskey H, Bogduk N. Classification of Chronic Pain. Descriptions of Chronic Pain Syndromes and Definition of Pain Terms, 2nd ed. Task Force on Taxonomy of the International Association for the Study of Pain. IASP Press, Seattle, 1994.

9. Manchikanti L, Boswell MV, Singh V, Pampati VS, Damron KS, Beyer $C D$. Prevalence of facet joint pain in chronic spinal pain of cervical, thoracic, and lumbar regions. BMC Musculoskelet Disord 2004; 5:15.

10. Manchukonda R, Manchikanti KN Cash KA, Pampati V, Manchikanti L. Facet joint pain in chronic spinal pain: An evaluation of prevalence and false-positive rate of diagnostic blocks. J Spinal Disord Tech 2007; 20:539-545.

11. Seghal N, Dunbar EE, Shah RV, Colson JD. Systematic review of diagnostic utility of facet (zygapophysial) joint injections in chronic spinal pain: An update. Pain Physician 2007; 10:213228.

12. Atluri $S$, Datta $S$, Falco FJE, Lee $M$. Systematic review of diagnostic utility and therapeutic effectiveness of thoracic facet joint interventions. Pain Physician 2008; 11:611-629.

13. Rubinstein SM, van Tulder M. A bestevidence review of diagnostic procedures for neck and low-back pain. Best Pract Res Clin Rheumatol 2008; 22:471-482.

14. Manchikanti L, Singh V, Pampati VS, Beyer CD, Damron KS. Evaluation of the prevalence of facet joint pain in chronic thoracic pain. Pain Physician 2002; 5:354-359.

15. Manchikanti L, Boswell MV, Singh V, Derby R, Fellows B, Falco FJE, Datta S, Smith HS, Hirsch JA. Comprehensive review of neurophysiologic basis and diagnostic interventions in managing chronic spinal pain. Pain Physician 2009; 12:E71-E120.

16. Manchikanti $L$, Boswell MV, Singh V, Benyamin RM, Fellows B, Abdi S, Buenaventura RM, Conn A, Datta S, Derby R, Falco FJE, Erhart S, Diwan S, Hayek SM, Helm S, Parr AT, Schultz DM, Smith HS, Wolfer LR, Hirsch JA. Comprehensive evidence-based guidelines for interventional techniques in the management of chronic spinal pain. Pain Physician 2009: 12:699802.

17. Manchikanti L, Boswell MV, Datta
S, Fellows B, Abdi S, Singh V, Benyamin RM, Falco FJE, Helm S, Hayek $S$, Smith HS. Comprehensive review of therapeutic interventions in managing chronic spinal pain. Pain Physician 2009; 12:E123-E198.

18. King W, Lau P, Lees R, Bogduk N. The validity of manual examination in assessing patients with neck pain. Spine J 2007; 7:22-26

19. Carragee EJ, Haldeman S, Hurwtiz E. The pyrite standard: The Midas touch in the diagnosis of axial pain syndromes. Spine J 2007; 7:27-31.

20. Bogduk N. In defense of King et al: The validity of manual examination in assessing patients with neck pain. Spine J 2007; 7:749-752.

21. Carragee EJ, Haldeman S, Hurwtiz E. Response to Bogduk. Letter to the Editor. Spine / 2007; 7:752-753.

22. Manchikanti L, Datta S, Derby R, Wolfer LR, Benyamin RM, Hirsch JA. A critical review of the American Pain Society clinical practice guidelines for interventional techniques: Part 1. Diagnostic interventions. Pain Physician 2010; 13:E141-E174.

23. Manchikanti L, Datta S, Gupta S, Munglani R, Bryce DA, Ward SP, Benyamin RM, Sharma ML, Helm II $S$, Fellows B, Hirsch JA. A critical review of the American Pain Society clinical practice guidelines for interventional techniques: Part 2. Therapeutic interventions. Pain Physician 2010; 13: E215-E264.

24. Manchikanti L, Shah RV, Datta S, Singh V. Critical evaluation of interventional pain management literature provides inaccurate conclusions. Spine J 2009; 9:706-708.

25. Smuck M, Levin JH: RE: Manchikant L, Singh V, Falco FJE, Cash KA, Fellows B. Cervical medial branch blocks for chronic cervical facet joint pain: A randomized double-blind, controlled trial with one-year follow-up. Spine (Phila $\mathrm{Pa}$ 1976) 2008; 33:1813-20. Spine (Phila Pa 1976) 2009; 34:1116.

26. Manchikanti L, Singh V, Falco FJE. In response to Smuck M, Levin JH. RE: Manchikanti L, Singh V, Falco FJE, Cash KA, Fellows B. Cervical medial branch blocks for chronic cervical facet joint pain: A randomized double-blind, controlled trial with oneyear follow-up. Spine (Phila Pa 1976) 2009; 34:1116-1117.
27. Levin JH. Prospective, double-blind, randomized placebo-controlled trials in interventional spine: What the highest quality literature tells us. Spine J 2009; 9:690-703.

28. Pham Dang C, Lelong A, Guilley J, Nguyen JM, Volteau C, Venet G, Perrier C, Lejus C, Blanloeil Y. Effect on neurostimulation of injectates used for perineural space expansion before placement of a stimulating catheter: Normal saline versus dextrose $5 \%$ in water. Reg Anesth Pain Med 2009; 34:398-403.

29. Tsui BC, Kropelin B, Ganapathy S, Finucane $B$. Dextrose $5 \%$ in water: Fluid medium maintaining electrical stimulation of peripheral nerve during stimulating catheter placement. Acta Anaesthesiol Scand 2005; 49:15621565.

30. Indahl A, Kaigle AM, Reikeräs O, Holm $\mathrm{SH}$. Interaction between the porcine lumbar intervertebral disc, zygapophysial joints, and paraspinal muscles. Spine (Phila Pa 1976) 1997; 22:28342840.

31. Indahl A, Kaigle A, Reikeräs $\mathrm{O}$, Holm $S$. Electromyographic response of the porcine multifidus musculature after nerve stimulation. Spine (Phila Pa 1976) $1995 ; 20: 2652-2658$.

32. Manchikanti L, Singh V, Derby $R$, Schultz DM, Benyamin RM, Prager JP, Hirsch JA. Reassessment of evidence synthesis of occupational medicine practice guidelines for interventional pain management. Pain Physician 2008; 11:393-482.

33. Manchikanti L, Derby R, Wolfer LR, Singh V, Datta S, Hirsch JA. Evidencebased medicine, systematic reviews, and guidelines in interventional pain management: Part 5. Diagnostic accuracy studies. Pain Physician 2009; 12:517-540.

34. Manchikanti L, Derby R, Wolfer LR, Singh V, Datta S, Hirsch JA. Evidencebased medicine, systematic reviews, and guidelines in interventional pain management: Part 7: Systematic reviews and meta-analyses of diagnostic accuracy studies. Pain Physician 2009; 12:929-963.

35. Manchikanti L, Pampati S, Cash KA. Making sense of accuracy of diagnostic lumbar facet joint nerve blocks: An assessment of implications of $50 \%$ relief, $80 \%$ relief, single block or controlled diagnostic blocks. Pain Physi- 
cian 2010; 13:133-143.

36. Pampati S, Cash KA, Manchikanti L. Accuracy of diagnostic lumbar facet joint nerve blocks: A 2-year follow-up of 152 patients diagnosed with controlled diagnostic blocks. Pain Physician 2009; 12:855-866.

37. Manchikanti L, Singh V, Falco FJ, Cash KA, Pampati V. Lumbar facet joint nerve blocks in managing chronic facet joint pain: One-year follow-up of a randomized, double-blind controlled trial: Clinical Trial NCT00355914. Pain Physician 2008; 11:121-132.

38. Manchikanti L, Singh V, Falco FJE, Cash KA, Pampati V. Evaluation of lumbar facet joint nerve blocks in managing chronic low back pain: A randomized, double-blind, controlled trial with a 2-year follow-up. Int J Med Sci 2010; 7:124-135.

39. Manchikanti L, Manchikanti K, Cash KA, Singh V, Giordano J. Age-related prevalence of facet joint involvement in chronic neck and low back pain. Pain Physician 2008; 11:67-75.

40. Manchikanti L, Boswell MV, Manchukonda R, Cash KA, Giordano J. Influence of prior opioid exposure on diagnostic facet joint nerve blocks. J Opioid Manage 2008, 4:351-360.

41. Manchikanti L, Pampati V, Damron KS, MCManus CD, Jackson SD, Barnhill RC, Martin JC. A randomized, prospective, double-blind, placebo-controlled evaluation of the effect of sedation on diagnostic validity of cervical facet joint pain. Pain Physician 2004; 7:301-309.

42. Manchikanti L, Damron KS, Rivera $J$, McManus CD, Jackson SD, Barnhill RC, Martin JC. Evaluation of effect of sedation as a confounding factor in the diagnostic validity of lumbar facet joint pain: A prospective, randomized, double-blind, placebocontrolled evaluation. Pain Physician 2004; 7:411-417.

43. Smith HS, Chopra P, Patel VB, Frey $M E$, Rastogi R. Systematic review on the role of sedation in diagnostic spinal interventional techniques. Pain Physician 2009; 12:195-206.

44. Falco FJE, Erhart S, Wargo BW, Bryce DA, Atluri S, Datta S, Hayek SM. Systematic review of diagnostic utility and therapeutic effectiveness of cervical facet joint interventions. Pain Physician 2009; 12:323-344.

45. Barnsley L, Lord SM, Wallis BJ, Bog- duk N. The prevalence of chronic cervical zygapophyseal joint pain after whiplash. Spine (Phila Pa 1976) 1995; 20:20-26.

46. Barnsley L, Lord S, Wallis B, Bogduk N. False-positive rates of cervical zygapophysial joint blocks. Clin J Pain 1993; 9:124-130.

47. Manchikanti L, Singh V, Derby R, Helm S, Trescot AM, Staats PS, Prager JP, Hirsch JA. Review of occupational medicine practice guidelines for interventional pain management and potential implications. Pain Physician 2008; 11:271-289.

48. Manchikanti L, Singh V, Helm S, Trescot AM, Hirsch JA. A critical appraisal of 2007 American College of Occupational and Environmental Medicine (ACOEM) practice guidelines for interventional pain management: An independent review utilizing AGREE, AMA, IOM, and other criteria. Pain Physician 2008; 11:291310.

49. Manchikanti $\mathrm{L}$, Singh $\mathrm{V}$, Falco FJE, Cash KA, Pampati V. Effectiveness of thoracic medial branch blocks in managing chronic pain: A preliminary report of a randomized, doubleblind controlled trial: Clinical Trial NCT00355706. Pain Physician 2008; 11:491-504.

50. Manchikanti L, Manchikanti KN, Manchukonda R, Pampati V, Cash KA. Evaluation of therapeutic thoracic medial branch block effectiveness in chronic thoracic pain: A prospective outcome study with minimum 1-year follow up. Pain Physician 2006; 9:97-105.

51. Manchikanti L, Singh V, Falco FJ, Cash KA, Fellows B. Cervical medial branch blocks for chronic cervical facet joint pain: A randomized double-blind, controlled trial with one-year follow-up. Spine (Phila Pa 1976) 2008; 33:1813-1820.

52. Manchikanti L, Singh V, Falco FJE, Cash KA, Fellows B. Comparative outcomes of a 2-year follow-up of cervical medial branch blocks in management of chronic neck pain: A randomized, double-blind controlled trial. Pain Physician 2010; 13:437-450.

53. Altman DG, Schulz KF, Moher D, Egger $M$, Davidoff F, Elbourne D, Gøtzsche PC, Lang T; CONSORT GROUP (Consolidated Standards of Reporting Trials). The revised CONSORT statement for reporting randomized trials: Ex- planation and elaboration. Ann Intern Med 2001; 134:663-694.

54. Manchikanti L, Hirsch JA, Smith HS. Evidence-based medicine, systematic reviews, and guidelines in interventional pain management: Part 2: Randomized controlled trials. Pain Physician 2008; 11:717-773.

55. Manchikanti L, Benyamin RM, Helm S, Hirsch JA. Evidence-based medicine, systematic reviews, and guidelines in interventional pain management: Part 3: Systematic reviews and meta-analysis of randomized trials. Pain Physician 2009; 12:35-72.

56. Jensen MP, Karoly P. Self-report scales and procedures for assessing pain in adults. In Turk DC, Melzack R (eds.). Handbook of Pain Assessment, 2nd Edition. Guilford Press; New York, 2001 pp 15-34.

57. Fairbank JC, Pynsent PB. The Oswestry Disability Index. Spine (Phila $\mathrm{Pa}$ 1976) 2000; 25:2940-2952.

58. Deyo RA, Battie $M$, Beurskens AJ, Bombardier C, Croft P, Koes B, Malmivaara $A$, Roland $M$, Von Korff $M$, Waddell $G$. Outcomes measures for low back pain research: A proposal for standardized use. Spine (Phila $\mathrm{Pa}$ 1976) 1998; 23:2003-2013.

59. Fairbank J, Couper J, Davies J, O'Brien JP. The Oswestry low back pain disability questionnaire. Physiotherapy 1980; 66:271-273.

60. Manchikanti L, Singh V, Smith HS, Hirsch JA. Evidence-based medicine, systematic reviews, and guidelines in interventional pain management: Part 4: Observational studies. Pain Physician 2009; 12:73-108.

61. Manchikanti L, Datta S, Smith HS, Hirsch JA. Evidence-based medicine, systematic reviews, and guidelines in interventional pain management: Part 6. Systematic reviews and metaanalyses of observational studies. Pain Physician 2009; 12:819-850.

62. Carragee EJ. The rise and fall of the "minimum clinically important difference." Spine J 2010; 10:283-284.

63. Carragee EJ, Chen I. Minimum acceptable outcomes after lumbar spinal fusion. Spine J 2010; 10:313-320.

64. Pereira J, Lawlor P, Vigano A, Dorgan $M$, Bruera E. Equianalgesic dose ratios for opioids. A critical review and proposals for long-term dosing. J Pain Symptom Manage 2001; 22:672-687. (Narcotic analgesic converter, Global- 
RPh Inc. http://www.globalrph.com/ narcotic.cgi)

65. Lord SM, Barnsley L, Wallis BJ, McDonald GJ, Bogduk N. Percutaneous radiofrequency neurotomy for chronic cervical zygapophysial joint pain. $N$ Engl J Med 1996; 335:1721-1726.

66. van Kleef $M$, Barendse $G A$, Kessels $A$, Weber WE, van Kleef M. Randomized trial of radiofrequency lumbar facet denervation for chronic low back pain. Spine (Phila Pa 1976) 1999; 24:1937-1942.

67. Koes BW, Scholten RJ, Mens JM, Bouter LM. Efficacy of epidural steroid injections for low-back pain and sciatica: A systematic review of randomized clinical trials. Pain 1995; 63:279288.

68. Hayashi N, Weinstein JN, Meller ST, Lee HM, Spratt KF, Gebhart GF. The effect of epidural injection of betamethasone or bupivacaine in a rat model of lumbar radiculopathy. Spine (Phila Pa 1976) 1998; 23:877-885.

69. Lee HM, Weinstein JN, Meller ST, Hayashi N, Spratt KF, Gebhart GF. The role of steroids and their effects on phospholipase A2. An animal model of radiculopathy. Spine (Phila Pa 1976) 1998; 23:1191-1196.

70. Johansson A, Hao J, Sjolund B. Local corticosteroid application blocks transmission in normal nociceptive $\mathrm{C}$ fibres. Acta Anaesthesiol Scand 1990; 34:335-338.

71. Pasqualucci A, Varrassi G, Braschi $A$, Peduto VA, Brunelli $A$, Marinangeli $F$, Gori F, Colò F, Paladini A, Mojoli F. Epidural local anesthetic plus corticosteroid for the treatment of cervical brachial radicular pain: Single injection versus continuous infusion. Clin J Pain 2007; 23:551-57.

72. Arner $S$, Lindblom $U$, Meyerson $B A$, Molander C. Prolonged relief of neuralgia after regional anesthetic block. A call for further experimental and systematic clinical studies. Pain 1990; 43:287-297.

73. Wertheim HM, Rovenstine EA. Suprascapular nerve block. Anesthesiology 1941; 2:541-545.

74. Riew KD, Park JB, Cho YS, Gilula L, Patel A, Lenke LG, Bridwell KH. Nerve root blocks in the treatment of lumbar radicular pain. A minimum fiveyear follow-up. J Bone Joint Surg Am 2006; 88:1722-1725.

75. Manchikanti L, Cash KA, McManus
CD, Pampati V, Smith HS. Preliminary results of randomized, equivalence trial of fluoroscopic caudal epidural injections in managing chronic low back pain: Part 1. Discogenic pain without disc herniation or radiculitis. Pain Physician 2008; 11:785-800.

76. Manchikanti L, Singh V, Cash KA, Pampati V, Damron KS, Boswell MV. Preliminary results of randomized, equivalence trial of fluoroscopic caudal epidural injections in managing chronic low back pain: Part 2. Disc herniation and radiculitis. Pain Physician 2008; 11:801-815.

77. Manchikanti L, Singh V, Cash KA, Pampati V, Datta S. Preliminary results of randomized, equivalence trial of fluoroscopic caudal epidural injections in managing chronic low back pain: Part 3. Post surgery syndrome. Pain Physician 2008; 11:817-831.

78. Manchikanti L, Cash KA, McManus $C D$, Pampati V, Abdi S. Preliminary results of randomized, equivalence trial of fluoroscopic caudal epidural injections in managing chronic low back pain: Part 4. Spinal stenosis. Pain Physician 2008; 11:833-848.

79. Manchikanti L, Singh V, Falco FJE, Cash KA, Pampati V. Evaluation of the effectiveness of lumbar interlaminar epidural injections in managing chronic pain of lumbar disc herniation or radiculitis: A randomized, doubleblind, controlled trial. Pain Physician 2010; 13:343-355.

80. Manchikanti L, Cash KA, McManus CD, Pampati V, Benyamin R. Preliminary results of a randomized, doubleblind, controlled trial of fluoroscopic lumbar interlaminar epidural injections in managing chronic lumbar discogenic pain without disc herniation or radiculitis. Pain Physician 2010; 13:E279-E292.

81. Manchikanti L, Cash KA, Pampati V Wargo BW, Malla Y. The effectiveness of fluoroscopic cervical interlaminar epidural injections in managing chronic cervical disc herniation and radiculitis: Preliminary results of a randomized, double-blind, controlled trial. Pain Physician 2010; 13:223236.

82. Manchikanti L, Cash KA, Pampati V Wargo BW, Malla Y. Cervical epidural injections in chronic discogenic neck pain without disc herniation or radiculitis: Preliminary results of a randomized, double-blind, controlled trial. Pain Physician 2010; 13:E265E278.

83. Lavoie PA, Khazen T, Filion PR. Mechanisms of the inhibition of fast axonal transport by local anesthetics. Neuropharmacology 1989; 28:175-181.

84. Bisby MA. Inhibition of axonal transport in nerves chronically treated with local anesthetics. Exp Neurol 1975; 47:481-489.

85. Katz WA, Rothenberg R. The nature of pain: Pathophysiology. J Clin Rheumatol 2005; 11:S11-15.

86. Melzack R, Coderre TJ, Katz J, Vaccarino AL. Central neuroplasticity and pathological pain. Ann NY Acad Sci 2001; 933:157-174.

87. Cassuto J, Sinclair R, Bonderovic M. Anti-inflammatory properties of local anesthetics and their present and potential clinical implications. Acta Anaesthesiol Scand 2006; 50:265-282.

88. Chou R, Huffman L. Evaluation and Management of Low Back Pain: Evidence Review. American Pain Society, Glenview, IL, 2009. www.ampainsoc. org/pub/pdf/LBPEvidRev.pdf

89. Chou R, Atlas SJ, Stanos SP, Rosenquist RW. Nonsurgical interventional therapies for low back pain: A review of the evidence for an American Pain Society clinical practice guideline. Spine (Phila Pa 1976) 2009; 34:10781093.

90. Carette S, Marcoux S, Truchon R, Grondin C, Gagnon J, Allard Y, Latulippe M. A controlled trial of corticosteroid injections into facet joints for chronic low back pain. $N$ Engl J Med 1991; 325:1002-1007.

91. Carette $S$, Leclaire R, Marcoux S, Morin $F$, Blaise GA, St-Pierre A, Truchon $R$, Parent $F$, Levesque J, Bergeron V, Montminy P, Blanchette C. Epidural corticosteroid injections for sciatica due to herniated nucleus pulposus. $N$ Engl J Med 1997; 336:1634-1640.

92. Birkenmaier C, Veihelmann A, Trouillier $\mathrm{HH}$, Hausdorf J, von Schulze Pellengahr C. Medial branch blocks versus pericapsular blocks in selecting patients for percutaneous cryodenervation of lumbar facet joints. Reg Anesth Pain Med 2007; 32:27-33.

93. Johnson CR, Barr RC, Klein SM. A computer model of electrical stimulation of peripheral nerves in regional anesthesia. Anesthesiology 2007; 106:323-30. 
94. Eippert F, Finsterbusch J, Bingel U, Büchel C. Direct evidence for spinal cord involvement in placebo analgesia. Science 2009; 326:404.

95. Bhatia MT, Parikh LCJ. Epidural saline therapy in lumbo-sciatic syndrome. $J$ Indian Med Assoc 1966; 47:537-542.

96. O'Neill C. Re: Manchikanti L, Singh V, Falco FJE, et al. Cervical medial branch blocks for chronic cervical facet joint pain. A randomized, double-blind, controlled trial with oneyear follow-up. Spine (Phila Pa 1976) 2008, 33:1813-1820. Spine (Phila Pa 1976) 2009; 34:1117-1118.

97. Saal JS. General principles of diagnostic testing as related to painful lumbar spine disorders. A critical appraisal of current diagnostic techniques. Spine (Phila Pa 1976) 2002;
27:2538-2545.

98. Roland $M$, Torgerson DJ. What are pragmatic trials? BMJ 1998; 316:285.

99. Tunis SR, Stryer DB, Clancy CM. Practical clinical trials. Increasing the value of clinical research for decision making in clinical and health policy. JAMA 2003; 290:1624-1632. 